\title{
Comparative SWOT Analysis for Water Solutions in Asia and Africa
}

\author{
Genia Nagara • Wei-Haur Lam • Nasha Chia Hwee Lee • \\ Faridah Othman • Md Ghazaly Shaaban
}

Received: 3 December 2013 / Accepted: 13 October 2014 /

Published online: 25 October 2014

(C) Springer Science+Business Media Dordrecht 2014

\begin{abstract}
Various scientific and technological based solutions such as virtual water trading, desalination, groundwater extraction and wastewater reuse have been proposed and implemented in many parts of Asia and Africa to relieve water scarcity. This paper applies SWOT (strengths, weaknesses, opportunities and threats) analysis to examine the suitability of these alternative water solutions to alleviate water scarcity. SWOT analysis proves to be a useful decision making tool as it provides a qualitative approach to simplify multilayer and interdisciplinary problems. The main input for the SWOT analysis consists of knowledge gathered from seven experts in the field of water and environmental sciences. The results show that compared to other solutions, wastewater reuse offers the most desirable qualities as a viable water solution for sustainable water management in Asia and Africa.
\end{abstract}

Keywords SWOTanalysis · Virtual water trading $\cdot$ Reverse osmosis desalination · Groundwater extraction Wastewater reuse

\section{Introduction}

Researchers may have varied perspectives regarding the looming water scarcity. However, for many arid regions in Asia and Africa, water sufficiency has been a major issue, and many countries in both continents have been struggling to meet their water demand. Central and West Asia and North Africa have been known as the most arid regions in the world. With their high population, these regions easily fall under the water scarce category with water availability below $1,000 \mathrm{~m}^{3}$ per capita (Rijsberman 2006). Falkenmark's index (Falkenmark et al.

G. Nagara $\cdot$ W.-H. Lam $(\square)$

State Key Laboratory of Hydraulic Engineering Simulation and Safety, Tianjin University, 92 Weijin Road, Nankai District, 300072 Tianjin, Peoples Republic of China

e-mail: joshuawhlam@hotmail.com

G. Nagara $\cdot$ W.-H. Lam $\cdot$ N. C. H. Lee $\cdot$ F. Othman $\cdot$ M. G. Shaaban

Department of Civil Engineering, Faculty of Engineering, University Malaya, 50603 Kuala Lumpur, Malaysia

N. C. H. Lee

School of Geography and the Environment, University of Oxford, South Parks Road, Oxford OX1 3QY, UK 
1989) categorizes a country with water availability below $1,700 \mathrm{~m}^{3}$ per capita as experiencing water stress, and below $1,000 \mathrm{~m}^{3}$ per capita as experiencing water scarcity. Moreover, rapid population growth coupled with high economic development in Asia and Africa will increase the gap between water demand and supply and thus it is predicted that $62 \%$ of the world's population, mostly located in these two continents, will experience water stress and water scarcity in 2030 (Wallace 2000). Water is one of the most essential elements in human life. Water scarcity not only affects human health but also affects a country's food security, and in turn can hinder the development of a nation.

Realizing the significant issue of water scarcity, Africa-Asia Development University Network (AADUN), a research-oriented collaboration amongst universities and institutions in Asia and Africa, has made sustainable water management as one of its main research targets. In addition, AADUN has been focusing its research in the following areas: renewable energy, ecosystems, women in science and technology development, food security, public health and disability studies in order to achieve its objectives, as indicated in the official website (www.aadun.org).

Water scarcity is a complex issue and the key to solve it will not only depend on the need to increase supply, but also to manage demand, or in other word a better 'water governance'(UNDP 2006). Nevertheless, many countries have focused their efforts on the increase supply-solution through exploring non-conventional water resources, as this approach is considered as the most politically feasible option within a country (Falkenmark et al. 2007). In many parts of Asia and Africa, non-conventional water solutions such as: virtual water trading (Allan 1993), reverse osmosis (RO) desalination, groundwater extraction and wastewater reuse have been proposed and employed to relieve water scarcity (Islam et al. 2007; Llamas and Martínez-Santos 2005; Nair and Kumar 2012; Yi et al. 2011). When utilizing these water solutions, it is important to have complete knowledge of their benefits, limitations and also their opportunities and risks as these solutions may not be suitable for each region. The main objective of this present paper is to evaluate the suitability of these water solutions to alleviate the water scarcity in Asia and Africa.

Many studies have reviewed the benefits, limitations, potentials and challenges of these water solutions at different levels, separately (Giordano 2009; Greenlee et al. 2009; Qadir et al. 2010; Warner 2003; Wichelns 2010; Miller 2006; Asano and Bahri 2010) or collectively, where LopezGunn and Ramón Llamas (2008) reviewed potentials and limitations of four scientific and technological innovations: virtual water trading, groundwater, desalination and Geographical Information System (GIS) and internet in addressing global water crisis. Therefore, the present paper will have four different focal points. First, the analysis will be focused on the conditions and challenges in Asia and Africa. Second, wastewater reuse is also included to the analysis as it has been an important water resource for many countries in Asia and Africa such as Singapore, China and MENA (North Africa and Middle East) countries. Third, in this paper the assessment of various benefits and limitations of these solutions will be carried out in one framework using SWOT (Strengths, Weaknesses, Opportunities and Threats) analysis. The SWOT analysis is used to clearly outline the important factors governing each solution that will provide usable information to assist decision makers. Fourth, the assessment will be conducted based on the perspectives from various experts in water and environmental sciences. The knowledge gathered from interviews with experts will be used as the main input for the SWOT analysis.

\section{Methodology}

SWOT Analysis is a decision making method that has been widely used in business management. SWOT analysis also has successfully been applied in identifying and solving problems related with water resource management which often involve interdisciplinary issues that are difficult to quantify (Kallioras et al. 2010; Mainali et al. 2011). In a similar manner, SWOT analysis will be 
applied to evaluate each water solution. This method is selected because it has the capacity to incorporate not only the present conditions (through strengths and weaknesses) but also the future conditions (through opportunities and threats) which is very important for Asia and Africa countries that are undergoing rapid changes especially in terms of population and economic development.

The present research adopts an expert interview approach to gather information. Knowledge and information collected through interviews with relevant experts will be used as the main input for the SWOT analysis. Expert interviews have been a popular method of gathering information in various fields of political and social sciences as it can provide insight and valuable knowledge in the relevant field and it is also considered as an efficient and concentrated method of gathering data especially in exploratory phase (Bogner et al. 2009).

Selecting the relevant experts is essential to gather usable information and successfully construct framework for analysing different water solutions. The experts interviewed for this research compose of people that work closely in the area of water and environmental sciences and who also have experiences in Asia and Africa regions. The list of their qualifications is provided in Table 1.

The interview was conducted through e-mail correspondences. The responses were collected from the respondents using a mixture of open-ended and scaled questions (Table 2). In order to provide a quantitative assessment, the respondents were also asked to rank their preferred water solution for arid region in Asia and Africa using the scale of 1 to 5 ( 1 being most unsuitable, 5 being most suitable).

Table 1 List of respondents and their qualifications

\begin{tabular}{|c|c|c|}
\hline Respondents & Qualifications & Field of expertise \\
\hline 1 & $\begin{array}{l}\text { This respondent is water research expert at the University of the Free State, } \\
\text { South Africa and has numerous publications especially in the field of } \\
\text { water security, including a think piece on Water and Energy in the } \\
\text { context of South Africa, papers on virtual water, hydropolitics, and the } \\
\text { South African water supply dilemma. }\end{array}$ & Academic researcher \\
\hline 2 & $\begin{array}{l}\text { This respondent is a Professor of Environmental Engineering at the } \\
\text { University of New Hampshire with research interest focused in water } \\
\text { treatment technologies. }\end{array}$ & Academic researcher \\
\hline 3 & $\begin{array}{l}\text { This respondent is a Professor of Environmental Engineering and Science at } \\
\text { the Stanford University. He has over } 300 \text { publications, and is co-author of } \\
\text { the textbooks, Chemistry for Environmental Engineering and Science and } \\
\text { Environmental Biotechnology - Principles and Applications. }\end{array}$ & Academic Researcher \\
\hline 4 & $\begin{array}{l}\text { This respondent is a Professor of Environmental Engineering at University } \\
\text { of Stavanger with research interest in water and wastewater treatment } \\
\text { and membrane technologies. }\end{array}$ & Academic Researcher \\
\hline 5 & $\begin{array}{l}\text { This respondent is a urban water management expert from the University } \\
\text { of Cape Town, South Africa with research interest focused on urban } \\
\text { water sustainability. }\end{array}$ & Academic Researcher \\
\hline 6 & $\begin{array}{l}\text { This respondent is a founder and president of a consulting firm in the field } \\
\text { of sustainable water and wastewater management and system planning } \\
\text { based in the Pacific region and also actively involves in initiatives for } \\
\text { the advancement of green infrastructure and sustainable water systems } \\
\text { in Hawai'i and developing countries. }\end{array}$ & Industry \\
\hline 7 & $\begin{array}{l}\text { This respondent is an environmental consultant on conservation, sustainable } \\
\text { development, and environmental education in the Asia Pacific region. }\end{array}$ & Consultant \\
\hline
\end{tabular}

Remarks: In order to provide the background information of the respondents as well as maintain their anonymity, the respondent's numbers and qualifications are randomised (the respondent's numbers and qualifications are not match) 
Link to Full-Text Articles :

http://umexpert.um.edu.my/file/publication/00003104 117534.pdf

http://link.springer.com/article/10.1007/s11269-014-0831-8 